\title{
Postoperative morbidity in pediatric patients following dental treatment under general anesthesia
}

\section{Purpose}

The aims of this study were to investigate post-operative complications in pediatric patients 24 and 72 hours after general anesthesia (GA) and to identify any associations between dental procedures and complications.

\section{Materials and Methods}

One hundred and thirty three healthy pediatric patients who had undergone dental treatment under GA (age range: two to nine years) were included in this study. The project was designed as a prospective, observational study supported by a questionnaire that collected data on children's post-operative complaints. Preoperative data were obtained from patients' files and included age, gender, medical condition and admission type (inpatient or outpatient) variables. The postoperative complaints were assessed either by phone contact or by face-to-face interviews using a questionnaire 24 and 72 hours after treatment.

\section{Results}

$69.9 \%$ of children reported one or more complaints after 24 hours and $35.3 \%$ after 72 hours. Coughing and pain (27.1\%), inability to eat (24.8\%), psychological changes $(24.1 \%)$ and a sore throat $(21.1 \%)$ were the most common complaints during the first day. After 72 hours, the severity and rate of the complications decreased significantly $(p<0.05)$.

\section{Conclusion}

Post-operative complaints following dental treatment under GA tended to be of mild severity and were mainly limited to the first day after the procedure.

Keywords: Children; dental care; general anesthesia; complication; postoperative

\author{
Merve Erkmen Almaz ${ }^{1}$ (D) \\ Aylin Akbay Oba ${ }^{1}$ (D), \\ Isil Saroglu Sonmez ${ }^{2}$ (D)
}

\section{Introduction}

Dental caries, which are the most prevalent chronic disease among children worldwide (1), may have life-long effects on oral health status $(2,3)$. Childhood caries cause pain, eating and swallowing problems, and missed days of school (4). Children with a history of pulpal symptoms also run a greater risk of dental anxiety and behavioral problems (5).

Limited co-operation and anxiety make dental treatment of children challenging for clinicians. Behavior management techniques can help gain children's co-operation (6). While most children can be treated in conventional settings, in some cases, routine treatment protocols are insufficient (7-9). In these cases, dental treatment under general anesthesia (GA) must be considered as an option (10). Given the risk of complication and mortality associated with GA, most parents consider it to be a dramatic departure from the traditional, office-based treatment approach for children (11). While death following dental treatment under GA is relatively rare among healthy children, complications are a common problem

Presented at: FDI Annual World Dental Congress, Istanbul, 2013.

ORCID IDs of the authors: M.E.A. 0000-0001-6766-2023; I.S.S. 0000-0002-3530-0244; A. A. $0.0000-0001-8820-8671$

'Department of Pediatric Dentistry, Faculty of Dentistry, Kirikkale University, Kirikkale, Turkey

${ }^{2}$ Department of Pediatric Dentistry, Faculty of Dentistry, Adnan Menderes University, Aydin, Turkey

Corresponding Author: Merve Erkmen Almaz E-mail: dt.merveerkmen@gmail.com

Received: 7 September 2018 Revised: 2 February 2019 Accepted: 7 February 2019

DOI: 10.26650/eor.20190023 
(12). Studies investigating post-operative complications in children after receiving dental treatment under GA have reported rates ranging from practically negligible to more than $90 \%$ of patients $(6,13-15)$.

The aims of this study were to investigate post-operative complications in pediatric patients at 24 hours (Day 1) and 72 hours (Day 3) following GA and to identify any associations between dental procedures and complications. The null hypothesis tested in the present research is that no difference could be found between the first and third days post-operation regarding the frequency and severity of the symptoms.

\section{Materials and Methods}

\section{Sample selection}

Ethical approval was obtained from the Kırıkkale University Clinical Research Ethics Committee (2010/89). The research was conducted in full accordance with the World Medical Association Declaration of Helsinki. The participants were recruited among children referred to Kırıkkale University's Faculty of Dentistry's Pediatric Dentistry Clinic due to their uncooperative behavior during dental examinations or their young age. The children had been identified as candidates for dental treatment under GA. Children with complex medical problems, such as Downs' syndrome, heart disease, mental retardation and cerebral palsy, were excluded. Only patients who were classified as Physical Status I or II, according to the American Society of Anesthesiologists (ASA), were included in the study. Accordingly, over a one-year period, the family and caregivers of healthy children were invited one by one to participate in the study, until 150 children (age range 2-9) were enrolled. Written consent was obtained from the parents and guardians of all the participants. This was a prospective observational study supported by a pre-formulated questionnaire that collected data on the children's postoperative complaints.

\section{Dental treatment under general anesthesia}

Children were prevented from eating and drinking for a sixhour period prior to the administration of GA. No preoperative medication was given to any of the participants. The majority of children $(78 \%)$ were administered intravenous propofol ( $2.0 \mathrm{mg} / \mathrm{kg}$ body weight); sevoflurane or a combination of sevoflurane and propofol was administered to the remaining children. The anesthesia was maintained with sevoflurane for all patients; rocuronium bromide $(0.5 \mathrm{mg} / \mathrm{kg}$ body weight) was used as a muscle relaxant; atropine $(0.2 \mathrm{mg} / \mathrm{kg}$ body weight) and neostigmine (0.05-0.07 mg/kg body weight) were used for recovery. As complications of nasal intubation are more common in young children (16), all patients were orally intubated, and a throat pack was used to prevent the aspiration of the secretions and dental materials. The cardiac functions were monitored with a 3-lead ECG. All patients received intravenous paracetamol (10 mg/kg body weight) intraoperatively as an analgesic. The anesthesia procedures were performed by one anesthesiologist, and dental treatments were completed under GA in a single session by the same pediatric dentist.

\section{Data collection}

All data were collected by a single investigator. Preoperative data were obtained from the patient record sheet that included information about patients' age, gender, medical condition and admission type (inpatient or outpatient). Dental data were reported as the mean number of treated teeth and the treatment type. Post-operative complications were assessed either by phone or by face-to-face interviews using a pre-formulated questionnaire after 24 hours (Day 1) and 72 hours (Day 3) (15).

\section{Statistical analysis}

Data were analyzed using the Statistical Package for Social Sciences software program (SPSS 15.0, SPSS Inc. Released 2007. SPSS for Windows, Version 15.0. Chicago, SPSS Inc., IL, USA). The normality of the dataset was checked with the Shapiro-Wilks test. As the data were not normally distributed, the non-parametric Mann-Whitney $U$ test was used to identify any significant differences between two scale variables after 24 and 72 hours. The chi-square test was used to examine the differences between frequency and severity of complications following dental procedures with GA after 24 and 72 hours. Fisher's exact test was used in place of the chi-square test when the expected values were less than five in the cell distribution. The confidence interval was set to $95 \%$, and $p$ values less than 0.05 were considered statistically significant.

\section{Results}

Of the 150 patients initially enrolled in the present study, 17 patients were excluded because their parent or guardian could not be reached post-operatively or because they refused to complete the questionnaire. The demographic characteristics of the remaining 133 patients are presented in Table 1. The mean age was $4.3( \pm 1.4)$ years. All patients were discharged after the procedure. The mean overall anesthesia time for GA procedures was $69.61 \mathrm{~min}$ (range: 10 to $165 \mathrm{~min}$ ).

The treatment provided under GA is presented in Table 2. The procedures included filling (Dyract Extra, Dentsply, DeTrey Konstanz, Germany) (mean number of teeth treated with fillings per child: $8.1 \pm 3.3$ ); endodontic treatment (Metapex, Meta Biomed Co. Ltd, Cheongju, Korea) (mean number of teeth treated endodontically per child: $1.3 \pm 1.4$ ); extractions (mean number of teeth treated by extraction per child: $2.6 \pm 2.4$ ); and sealant application (Clinpro sealant,

Table 1. Patient demographic variables and duration of anesthesia.

\begin{tabular}{lcc} 
Variable & & N (\%) \\
\hline Gender & Male & $83(62)$ \\
\cline { 2 - 3 } & Female & $50(38)$ \\
\hline \multirow{2}{*}{ Age } & $\leq 5$ & $104(78)$ \\
\cline { 2 - 3 } & $>5$ & $29(22)$ \\
\hline Anesthesia duration (min) & $<70$ & $72(54)$ \\
\cline { 2 - 3 } & $\geq 70$ & $61(46)$ \\
\hline
\end{tabular}


Table 2. Treatment types provided under general anesthesia.

\begin{tabular}{lcc} 
Type of treatment & Mean number $( \pm \text { SD })^{* *}$ & Range \\
\hline Filling & $8.1 \pm 3.3$ & $1-17$ \\
\hline Pulpotomy & $0.9 \pm 1.1$ & $1-5$ \\
\hline Pulpectomy & $0.4 \pm 0.9$ & $1-4$ \\
\hline Fissure sealant & $0.2 \pm 0.8$ & $1-4$ \\
\hline Extraction & $2.6 \pm 2.4$ & $1-14$ \\
\hline
\end{tabular}

*All children received fluoride treatment.

**For those children receiving this type of treatment ${ }^{3}$

3M ESPE, Seefield/Oberbay, Germany) (mean number of teeth treated with sealant per child: $0.2 \pm 0.8)$. In addition, all patients received fluoride varnish (Duraphat Varnish, Colgate-Palmolive, NSW, Australia), which was applied topically. Table 3 shows the frequency of complications on the first (24 hours) and the third (72 hours) days post-operation. While $69.9 \%$ of children had one or more complaint after 24 hours, the rate decreased to $35.3 \%$ after 72 hours. The most common complaints after 24 hours were coughing (27.1\%), dental pain $(27.1 \%)$, inability to eat $(24.8 \%)$, psychological changes $(24.1 \%)$ and a sore throat $(21.1 \%)$, whereas the most common complaints after 72 hours were psychological changes (14.3\%), coughing (16.5\%) and inability to eat (9.0\%). The severity and frequency of complications after 24 and 72 hours post-operation are presented in Table 4 and Table 5. Statistical analysis indicated a significant reduction in the severity of complaints from day 1 to day 3 . In addition, the complaint of an inability to eat was found to be significantly related to the number of teeth extracted ( $p$ $<0.05$ ). There was no significant relationship between postoperative dental pain and treatment type or number of teeth treated under GA. Also, no significant relationship was found between post-operative dental bleeding and the number of teeth extracted.

Table 3. Frequencies of complications on Days 1 and 3 following pediatric dental procedures with general anesthesia.

\begin{tabular}{|c|c|c|c|c|c|}
\hline \multirow{2}{*}{ Post-operative complaints } & \multicolumn{2}{|c|}{$\begin{array}{c}\text { Complaints after } \\
1 \text { day }\end{array}$} & \multicolumn{2}{|c|}{$\begin{array}{c}\text { Complaints after } \\
3 \text { days }\end{array}$} & \multirow{2}{*}{ p value } \\
\hline & $\mathbf{n}$ & $(\%)$ & $\mathbf{n}$ & (\%) & \\
\hline Dental pain & 36 & 27.1 & 7 & 5.3 & 0.016 \\
\hline Dental bleeding & 22 & 16.5 & 3 & 2.3 & 0.004 \\
\hline Sore throat & 28 & 21.1 & 9 & 6.8 & 0.000 \\
\hline Fever & 21 & 15.8 & 5 & 3.8 & 0.002 \\
\hline Vomiting & 13 & 9.8 & 4 & 3.0 & 0.003 \\
\hline Inability to eat & 33 & 24.8 & 12 & 9.0 & 0.000 \\
\hline Sleepiness & 20 & 15.0 & 4 & 3.0 & 0.011 \\
\hline Drowsiness & 23 & 17.3 & 3 & 2.3 & 0.005 \\
\hline Nausea & 16 & 12.0 & 6 & 4.5 & 0.002 \\
\hline Psychological changes & 32 & 24.1 & 22 & 16.5 & 0.000 \\
\hline Coughing & 36 & 27.1 & 19 & 14.3 & 0.000 \\
\hline
\end{tabular}

Table 4. Frequency/severity of complications on Day 1 (24 h) following pediatric dental procedures with general anesthesia.

\begin{tabular}{|c|c|c|c|c|c|c|c|c|}
\hline \multirow{2}{*}{$24 \mathrm{~h}$} & \multicolumn{2}{|c|}{ None } & \multicolumn{2}{|c|}{ Mild } & \multicolumn{2}{|c|}{ Moderate } & \multicolumn{2}{|c|}{ Severe } \\
\hline & $\mathbf{n}$ & $\%$ & $\mathbf{n}$ & $\%$ & $\mathbf{n}$ & $\%$ & $\mathbf{n}$ & $\%$ \\
\hline Dental pain & 97 & 72.9 & 24 & 18.0 & 8 & 6.0 & 4 & 3.0 \\
\hline Dental bleeding & 111 & 83.5 & 19 & 14.3 & 2 & 1.5 & 1 & 0.8 \\
\hline Sore throat & 105 & 78.9 & 15 & 11.3 & 8 & 6.0 & 5 & 3.8 \\
\hline Fever & 112 & 84.2 & 13 & 9.8 & 4 & 3.0 & 4 & 3.0 \\
\hline Vomiting & 120 & 90.2 & 11 & 8.3 & 2 & 1.5 & 0 & 0.0 \\
\hline Inability to eat & 100 & 75.2 & 33 & 24.8 & 0 & 0.0 & 0 & 0.0 \\
\hline Sleepiness & 113 & 85.0 & 20 & 15.0 & 0 & 0.0 & 0 & 0.0 \\
\hline Drowsiness & 110 & 82.7 & 23 & 17.3 & 0 & 0.0 & 0 & 0.0 \\
\hline Nausea & 117 & 88.0 & 16 & 12.0 & 0 & 0.0 & 0 & 0.0 \\
\hline Psychological changes & 101 & 75.9 & 32 & 24.1 & 0 & 0.0 & 0 & 0.0 \\
\hline Coughing & 97 & 72.9 & 36 & 27.1 & 0 & 0.0 & 0 & 0.0 \\
\hline
\end{tabular}


Table 5. Frequency/severity of the complications on Day $3(72 \mathrm{~h})$ following pediatric dental procedures with $G A$.

\begin{tabular}{|c|c|c|c|c|c|c|c|c|}
\hline \multirow{2}{*}{$72 \mathrm{~h}$} & \multicolumn{2}{|c|}{ None } & \multicolumn{2}{|c|}{ Mild } & \multicolumn{2}{|c|}{ Moderate } & \multicolumn{2}{|c|}{ Severe } \\
\hline & $\mathbf{n}$ & $\%$ & $\mathbf{n}$ & $\%$ & $\mathbf{n}$ & $\%$ & $\mathbf{n}$ & $\%$ \\
\hline Dental pain & 126 & 94.7 & 4 & 3.0 & 2 & 1.5 & 1 & 0.8 \\
\hline Dental bleeding & 130 & 97.7 & 3 & 2.3 & 0 & 0.0 & 0 & 0.0 \\
\hline Sore throat & 124 & 93.2 & 7 & 5.3 & 1 & 0.8 & 1 & 0.8 \\
\hline Fever & 128 & 96.2 & 3 & 2.3 & 1 & 0.8 & 1 & 0.8 \\
\hline Vomiting & 129 & 97.0 & 3 & 2.3 & 1 & 0.8 & 0 & 0.0 \\
\hline Inability to eat & 121 & 91.0 & 12 & 9.0 & 0 & 0.0 & 0 & 0.0 \\
\hline Sleepiness & 129 & 97.0 & 4 & 3.0 & 0 & 0.0 & 0 & 0.0 \\
\hline Drowsiness & 130 & 97.7 & 3 & 2.3 & 0 & 0.0 & 0 & 0.0 \\
\hline Nausea & 127 & 95.5 & 6 & 4.5 & 0 & 0.0 & 0 & 0.0 \\
\hline Psychological changes & 111 & 83.5 & 22 & 16.5 & 0 & 0.0 & 0 & 0.0 \\
\hline Coughing & 114 & 85.7 & 19 & 14.3 & 0 & 0.0 & 0 & 0.0 \\
\hline
\end{tabular}

\section{Discussion}

Dental treatment under GA is essential for some pediatric patients who require comprehensive dental care but who cannot be treated with local anesthesia and do not respond to standard behavioral management techniques. This study was carried out to examine the nature, severity and duration of post-operative complications in healthy pediatric patients following comprehensive dental treatment under GA.

More than two-thirds of the patients in the present study reported one or more complaints 24 hours after the GA procedure. The number and severity of complaints decreased significantly after 72 hours. These results were consistent with those of several previous studies (15, 17-19). Farsi et al. (15), Atan et al. (17) and Escanilla-Casal et al. (18) also reported a significant reduction in patients' complaints 72 hours after GA procedures.

About one-third of children in the present study experienced dental pain during the first day after GA. This rate is higher than the rate reported by Enever et al. (13). The difference could be due to the smaller sample size of the earlier study. Farsi et al. (15), Atan et al. (17) and Escanilla-Casal et al. (18) reported higher rates of pain than the present study. This could be explained by the different dental treatments applied to patients. In the present study, both the rate and severity of pain were found to be significantly lower at 72 hours than at 24 hours. This finding is in line with previous reports $(15,17$, $18,20)$. The present study found no significant relationship between post-operative dental pain and treatment type or number of teeth treated under GA. This is inconsistent with the findings of Farsi et al. (15), who reported a significant, positive correlation between post-operative dental pain and the number of procedures performed.

Sleepiness, drowsiness, nausea and vomiting are types of complications that could be related to GA. Nausea, vomiting and drowsiness have been reported to occur in connection with the use of the anesthetic agents, such as sevoflurane and propofol $(21,22)$. In the present study, reports of nausea, vomiting and drowsiness during the first day occurred at similar rates, and the majority of complications were classified as "mild" severity. After 72 hours, reported rates of nausea, vomiting and drowsiness were all below 5\%. Farsi et al. (15) also reported a reduction in the rate and severity of nausea, vomiting and drowsiness after 72 hours. This may be due to the elimination of drugs from the body. Previous studies found post-operative sleepiness was related to the anesthesia duration $(15,17)$; however, the present study found no such significant relationship.

In the present study, almost $25 \%$ of patients complained about an inability to eat 24 hours post-operation; moreover, this complaint was found to be significantly related to the number of teeth extracted. Similarly, Farsi et al. (15) reported that complaints of a sore throat, coughing, pain and vomiting, as well as an inability to eat, decreased by the third day following GA. The complaint of an inability to eat could be associated with the other complaints mentioned (15).

The nasotracheal intubation is more physically traumatic than the orotracheal one (23). It causes an increase in postoperative problems due to the trauma $(23,24)$, and these complications of have been reported to be more common in young children (16). Therefore, the orotracheal approach was preferred for all patients. Although the tube's position limited the working space, none of the cases presented with dental or soft tissue injury resulting from the orotracheal intubation. The reported complications of orotracheal intubation include sore throat, laryngeal edema, hoarseness, nerve injury, aspiration of oral or gastric contents, superficial laryngeal ulcers and laryngeal granuloma (25). Among these, we only encountered sore throat.

In the present study, complaints of a sore throat and coughing were reported by more than $20 \%$ of patients on the first day. This rate is similar to those reported by EscanillaCasal et al. (18) and Farsi et al. (15) and could be the result of the traumatic intubation and throat pack used by pediatric dentists to prevent aspiration of secretions and dental materials (15). In the present study, these complaints were found to be significantly lower on the third day compared the first.

Some previous studies have reported post-operative fever $(15,18,26)$. Escanilla-Casal et al. (18) reported a $9 \%$ rate of 
post-operative fever in ASA I patients after treatment under GA, and Farsi et al. (15) reported a rate of $21 \%$ among healthy children, which is similar to the present study's rate of $16 \%$. Escanilla-Casal et al. (18) mentioned various factors that could be associated with post-operative fever after GA procedures, including tissue destruction, operating-room temperature, medications and dehydration. Farsi et al. (15) suggested that preoperative fasting and the inability to eat post-operatively could cause dehydration, which could also cause fever in children.

In the present study, psychological changes were reported in $24 \%$ of children in the first day post-operation, but only in $14 \%$ on the third day. Previous studies reported higher rates of behavioral changes in children who had been anesthetized with sevoflurane than in those with halothane $(27,28)$. The anesthesia procedures could impact the psychology and behavior of children, especially since children who were treated with GA already had dental fear and were unable to comply with local anesthesia and standard behavior management procedures. It is also important to note that the present study included children between the ages of two and nine, and younger children, especially those under the age of six, might have difficulties accurately expressing their signs and symptoms.

Surprisingly, no relationship was found between postoperative dental bleeding and the number of teeth extracted. This is in contrast to the findings of previous studies $(15,16,29$, 30) and could be related to the reduction in bleeding caused by the vasoconstrictor contained in the local anesthesia, which was used prior to extraction.

\section{Conclusion}

Post-operative complaints following dental treatment under GA tended to be of mild severity and were mainly limited to the first day following treatment. Given the low rates of postoperative complications, dental treatment under GA could be considered an important and useful treatment option for children whose lack of compliance makes conventional dental procedures impossible.

Türkçe Öz: Pediatrik hastalarda genel anestezi altında diş tedavilerini takiben görülen postoperatif morbiditeler. Amaç: Bu çalışmanın amaçlarl; pediatrik hastalarda genel anestezi (GA) sonrası 24 ve 72 . saatlerde postoperatif morbiditeleri araştırmak ve dental prosedürler ve morbiditeler arasındaki bir ilişki olup olmadığını tanımlamaktır. Gereç ve Yöntem: Genel anestezi altında diş tedavisi yapılan 133 sağlıklı çocuk hasta (yaş aralığı 2-9) çalışmaya dahil edilmiştir. Bu çalışma, bir anket yardımıyla çocukların postoperatif şikayetleri hakkında veri toplanarak prospektif, gözlemsel bir çalışma olarak tasarlanmıştır. Preoperatif veriler hasta kayıtlarından elde edilerek, hastanın yaşı, cinsiyeti, medikal durumu ve kabul türü (ayakta/yatan hasta) kaydedilmiştir. Postoperatif morbiditeler telefonla veya yüz yüze görüşmelerle, 24 ve 72 saat sonra bir anket yardımıyla kaydedilerek değerlendirilmiştir. Bulgular: Çocukların \% 69.9'unun 24 saat sonunda bir veya daha fazla şikayeti olduğu, 72 saat sonunda ise bu oranın sadece \% 35.3 olduğu öğrenilmiştir. Birinci gün en sık görülen şikayetler; öksürük ve ağrı (\% 27.1), yemek yemede güçlük (\% 24.8), psikolojik değişiklikler (\% 24.1) ve boğaz ağrısı (\% 21.1) olarak kaydedilmiştir. 72 saat sonunda morbidite şiddeti ve oranlarında anlamlı azalma gözlenmiştir $(p<0.05)$. Sonuçlar: GA altında diş tedavilerini takiben postoperatif şikayetler hafif şiddette olma eğilimindedir ve çoğunlukla tedaviyi takip eden ilk gün ile sınırlı kalmaktadır. Anahtar Kelimeler: Çocuk; diş tedavisi; genel anestezi; morbidite, postoperative
Ethics Committee Approval: The ethical approval was obtained from the Kırıkkale University Clinical Research Ethics Committee (2010/89).

Informed Consent: Patients' parents provided the informed consents.

Peer-review: Externally peer-reviewed.

Author contributions: AAO and ISS designed the study. MEA participated in generating the data and gathering the data for the study. MEA and AAO participated in the analysis of the data. MEA wrote the majority of the original draft of the paper. MES and ISS participated in writing the paper. All authors approved the final version of this paper.

Conflict of Interest: The author had no conflict of interest to declare. Financial Disclosure: The author declared that this study has received no financial support.

\section{References}

1. Kaste LM, Selwitz RH, Oldakowski RJ, Brunelle JA, Winn DM, Brown LJ. Coronal caries in the primary and permanent dentition of children and adolescents 1-17 years of age: United States, 1988-1991. J Dent Res 1996;75:631-41. [CrossRef]

2. Almaz ME, Sonmez IS, Oba AA, Alp S. Assessing changes in oral health-related quality of life following dental rehabilitation under general anesthesia. J Clin Pediatr Dent 2014;38(3):263-7. [CrossRef]

3. Low W, Tan S, Schwartz S. The effect of severe caries on the quality of life in young children. Ped Dent 1999;21(6):325-6.

4. Jamieson WJ, Vargas K. Recall rates and caries experience of patients undergoing general anesthesia for dental treatment. Ped Dent 2007;29(3):253-7.

5. Jalevik B, Klingberg GA. Dental treatment, dental fear and behaviour management problems in children with severe enamel hypomineralization of their permanent first molars. Int J Ped Dent 2002;12(1):24-32. [CrossRef]

6. Vinckier F, Gizani S, Declerck D. Comprehensive dental care for children with rampant caries under general anaesthesia. Int J Ped Dent 2001;11(1):25-32. [CrossRef]

7. Anderson HK, Drummond BK, Thomson WM. Changes in aspects of children's oral-health-related quality of life following dental treatment under general anaesthesia. Int J Ped Dent 2004;14(5):317-25. [CrossRef]

8. Malden PE, Thomson WM, Jokovic A, Locker D. Changes in parent-assessed oral health-related quality of life among young children following dental treatment under general anaesthetic. Community Dent Oral Epidemiol 2008;36(2):108-117. [CrossRef]

9. Nunn JH, Davidson G, Gordon PH, Storrs J. A retrospective review of a service to provide comprehensive dental care under general anesthesia. Spec Care Dentist 1995;15(3):97-101. [CrossRef]

10. Klaassen MA, Veerkamp JS, Hoogstraten J. Dental treatment under general anaesthesia: the short-term change in young children's oral-health-related quality of life. Eur Arch Paed Dent 2008;9(3):130-7. [CrossRef]

11. White $H$, Lee JY, Vann WF, Jr. Parental evaluation of quality of life measures following pediatric dental treatment using general anesthesia. Anesthesia progress. 2003;50(3):105-10.

12. Krippaehne JA, Montgomery MT. Morbidity and mortality from pharmacosedation and general anesthesia in the dental office. J Oral Maxillofac Surg 1992;50(7):691-8. [CrossRef]

13. Enever GR, Nunn JH, Sheehan JK. A comparison of postoperative morbidity following outpatient dental care under general anaesthesia in paediatric patients with and without disabilities. Int J Ped Dent 2000;10(2):120-5. [CrossRef]

14. Holt RD, Chidiac RH, Rule DC. Dental treatment for children under general anaesthesia in day care facilities at a London dental hospital. Br Dent J 1991;170(7):262-6. [CrossRef] 
15. Farsi N, Ba'akdah R, Boker A, Almushayt A. Postoperative complications of pediatric dental general anesthesia procedure provided in Jeddah hospitals, Saudi Arabia. BMC Oral Health 2009;19:6. [CrossRef]

16. Black AE, Hatch DJ, Nauth-Misir N. Complications of nasotracheal intubation in neonates, infants and children: a review of 4 years' experience in a children's hospital. Br J Anaesth. 1990;65(4):4617. [CrossRef]

17. Atan S, Ashley P, Gilthorpe MS, Scheer B, Mason C, Roberts G. Morbidity following dental treatment of children under intubation general anaesthesia in a day-stay unit. Int J Ped Dent 2004;14(1):9-16. [CrossRef]

18. Escanilla-Casal A, Ausucua-Ibanez M, Aznar-Gomez M, VianoGarcia JM, Sentis-Vilalta J, Rivera-Baro A. Comparative study of postoperative morbidity in dental treatment under general anesthesia in pediatric patients with and without an underlying disease. Int J Ped Dent 2016;26(2):141-8. [CrossRef]

19. Hosey MT, Macpherson LM, Adair P, Tochel C, Burnside G, Pine C. Dental anxiety, distress at induction and postoperative morbidity in children undergoing tooth extraction using general anaesthesia. Br Dent J. 2006;200(1):39-43. [CrossRef]

20. Jensen B. Post-operative pain and pain management in children after dental extractions under general anaesthesia. Eur Arch Paed Dent 2012;13(3):119-25. [CrossRef]

21. Hong JY, Oh JI, Kim SM. Comparison of sevoflurane-nitrous oxide and target-controlled propofol with fentanyl anesthesia for hysteroscopy. Yonsei Med J 2002;43(4):420-6. [CrossRef]
22. Jokela RM, Kangas-Saarela TA, Valanne JV, Koivuranta MK, Ranta PO, Alahuhta SM. Postoperative nausea and vomiting after sevoflurane with or without ondansetron compared with propofol in female patients undergoing breast surgery. Anesth Analg 2000;91(5):1062-5. [CrossRef]

23. Hall CEJ, Shutt LE. Nasotracheal intubation for head and neck surgery. Anaesthesia 2003;58(3):249-56. [CrossRef]

24. Prasanna D, Bhat S. Nasotracheal Intubation: An Overview. J Maxillofac Oral Surg 2014;13(4):366-72. [CrossRef]

25. Divatia JV, Bhowmick K. Complications of endotracheal intubation and other airway management procedures. Indian J. Anaesth 2005;49(4):308-18.

26. Chia-Ling T Y-LT, Yng-Tzer L, Yai-Tin L. A retrospective study of dental treatment under general anesthesia of children with or without a chronic illness and/or a disability. Chang Gung Med J 2006;29:408-12.

27. Breschan C, Platzer M, Jost R, Stettner H, Likar R. Midazolam does not reduce emergence delirium after sevoflurane anesthesia in children. Paediatr Anaesth 2007;17(4):347-52. [CrossRef]

28. Keaney A, Diviney D, Harte S, Lyons B. Postoperative behavioral changes following anesthesia with sevoflurane. Paediatr Anaesth 2004;14(10):866-70. [CrossRef]

29. Al-Bahlani S, Sherriff A, Crawford PJ. Tooth extraction, bleeding and pain control. J R Coll Surg Edinb 2001;46(5):261-4.

30. Coulthard P, Rolfe S, Mackie IC, Gazal G, Morton M, JacksonLeech D. Intraoperative local anaesthesia for paediatric postoperative oral surgery pain--a randomized controlled trial. Int J Oral Maxillofac Surg 2006;35(12):1114-9. [CrossRef] 